\title{
Surface Ozone Episode Due to Stratosphere-Troposphere Exchange and Free Troposphere-Boundary Layer Exchange in Busan During Asian Dust Events
}

\author{
Y. S. Moon ${ }^{a}$, Y. K. Kim ${ }^{b}$, K. Strong ${ }^{a}$, S. H. Kim \\ Y. K. Lim ${ }^{b}$, I. B. Oh ${ }^{b}$, and S. K. Song \\ ${ }^{a}$ Department of Physics, University of Toronto, Toronto, Canada \\ ${ }^{b}$ Department of Atmospheric Sciences, Pusan National University, Busan, South Korea \\ ${ }^{c}$ Meteorological Research Institute, Korean Meteorological Agency, Seoul, South Korea
}

(Manuscript received 4 May, 2002 ; accepted 14 May, 2002)

\begin{abstract}
The current paper reports on the enhancement of $\mathrm{O}_{3}, \mathrm{CO}, \mathrm{NO}_{2}$, and aerosols during the Asian dust event that occurred over Korea on 1 May 1999. To confirm the origin and net flux of the $\mathrm{O}_{3}, \mathrm{CO}, \mathrm{NO}_{2}$, and aerosols, the meteorological parameters of the weather conditions were investigated using Mesoscale Meteorological Model 5(MM5) and the TOMS total ozone and aerosol index, the back trajectory was identified using the Hybrid Single-Particle Lagrangian Integrated Trajectory Model(HYSPLIT), and the ozone and ozone precursor concentrations were determined using the Urban Ashed Model(UAM). In the presence of sufficiently large concentrations of $\mathrm{NO}_{x}$, the oxidation of $\mathrm{CO}$ led to $\mathrm{O}_{3}$ formation with $\mathrm{OH}, \mathrm{HO}_{2}$, $\mathrm{NO}$, and $\mathrm{NO}_{2}$ acting as catalysts. The sudden enhancement of $\mathrm{O}_{3}, \mathrm{CO}, \mathrm{NO}_{2}$ and aerosols was also found to be associated with a deepening cut-off low connected with a surface cyclone and surface anticyclone located to the south of Korea during the Asian dust event. The wave pattern of the upper trough/cut-off low and total ozone level remained stationary when they came into contact with a surface cyclone during the Asian dust event. A typical example of a stratospheretroposphere exchange(STE) of ozone was demonstrated by tropopause folding due to the jet stream. As such, the secondary maxima of ozone above $80 \mathrm{ppbv}$ that occurred at night in Busan, Korea on 1 May 2001 were considered to result from vertical mixing and advection from a free troposphere-boundary layer exchange in connection with an STE in the upper troposphere. Whereas the sudden enhancement of ozone above 100 ppbv during the day was explained by the catalytic reaction of ozone precursors and transport of ozone from a slow-moving anticyclone area that included a high level of ozone and its precursors coming from China to the south of Korea. The aerosols identified in the free troposphere over Busan, Korea on 1 May 1999 originated from the Taklamakan and Gobi deserts across the Yellow River. In particular, the $1000 \mathrm{~m}$ profile indicated that the source of the air parcels was from an anticyclone located to the south of Korea. The net flux due to the first invasion of ozone between 0000 LST and 0600 LST on 1 May 1999 agreed with the observed ground-based background concentration of ozone. From 0600 LST to 1200 LST, the net flux of the second invasion of ozone was twice as much as the day before. In this case, a change in the horizontal wind direction may have been responsible for the ozone increase.
\end{abstract}

Key words : STE, tropopause folding, vertical mixing and advection, free troposphere-boundary layer exchange, catalytic reaction, transport, net flux

Corresponding author ; Yun-Seob Moon, Dept. of Physics, University of Toronto, Toronto, Ontario M5S 1A7, Canada

Phone : +1-416-946-3217

E-mail : ysmoon@atmosp.physics.utoronto.ca

\section{Introduction}

Over the last few decades, the production of ozone $\left(\mathrm{O}_{3}\right)$ in the Northern Hemisphere mid-latitude zone has been strongly enhanced by rapidly in- 
creasing nitrogen oxide $\left(\mathrm{NO}_{\mathrm{x}}\right)$-rich environments due to industrial activities. Many efforts have already been made to interpret the daily and seasonal variations in the amount of surface ozone resulting from the influence of various meteorological phenomena and chemical reactions ${ }^{1)}$. Tropospheric ozone originates from two sources: formation and transport from chemical processes among tropospheric trace gases and intermittent engulfment of stratospheric ozone in the troposphere ${ }^{2-8)}$. Girdziene ${ }^{2)}$ indicated that the highest ozone concentrations are connected with an efficient stratosphere-troposphere exchange (STE). As such, the summer ozone peak is the result of anthropogenic pollution and photochemical processes. However, there is still disagreement about the relative importance of these two sources, mainly because of the difficulties in estimating the contribution from chemical production. Ozone chemistry in the troposphere is very sensitive to the concentrations of ozone precursors $\left(\right.$ e.g. $\mathrm{NO}_{\mathrm{x}}, \mathrm{H}_{2} \mathrm{O}$, $\mathrm{CO}$, and hydrocarbons) whose distributions are highly variable and not well known.

Pazenny and Brasseur" ${ }^{9)}$ and ${\mathrm{H} ø v^{77}}^{7}$ pointed out that the most important tropospheric ozone precursors are nitrogen oxides $\left(\mathrm{NO}_{\mathrm{x}}=\mathrm{NO}+\mathrm{NO}_{2}\right)$, carbon monoxide $(\mathrm{CO})$, methane $\left(\mathrm{CH}_{4}\right)$, and other 'nonmethane' hydrocarbons(NMHCs). All these precursors are products of fossil fuel and biomass burning, yet each also has significant sources from the biosphere. The only ozone sinks are depositions on the surface(vegetation, soil, and oceans), chemical destruction, and a return to the stratosphere in the tropics. It is believed that the increase in the ozone observed in near-surface air is the result of increased $\mathrm{NO}_{\mathrm{x}}$ emission. Jaegle et $a l^{10)}$. also examined the origin of $\mathrm{NO}_{x}$ in the upper troposphere together with $\mathrm{NO}, \mathrm{NO}_{\mathrm{y}}, \mathrm{N}_{2} \mathrm{O}, \mathrm{O}_{3}, \mathrm{OH}, \mathrm{HO}_{2}$, $\mathrm{H}_{2} \mathrm{O}, \mathrm{CO}, \mathrm{CO}_{2}, \mathrm{CH}_{4}$, and aerosol observations over the central United States in April-May of 1996. Observational data on the correlation between $\mathrm{NO}_{\mathrm{y}}$ (sum of $\mathrm{NO}_{\mathrm{x}}$ and its oxidation products) and $\mathrm{CO}$ at an $8-12 \mathrm{~km}$ altitude indicated that $\mathrm{NO}_{\mathrm{x}}$ originated primarily from the convective transport of polluted boundary-layer air. Lightning and aircraft emissions only appeared as minor sources of $\mathrm{NO}_{\mathrm{x}}$. The $\mathrm{CO}$ in the troposphere can be oxidized by $\mathrm{OH}$ molecules that originate from the $\mathrm{O}_{3}$ transported across the tropopause ${ }^{11)}$. The major sources of $\mathrm{CO}$ are the oxidation of $\mathrm{CH}_{4}$ via formaldehyde( $\mathrm{HCHO}$ ), biomass burning, oxidation of hydrocarbons (mainly natural), and fossil-fuel combustion. The main sink of $\mathrm{CO}$ is $\mathrm{OH}$ oxidation into $\mathrm{CO}_{2}$, with smaller sinks due to consumption by soils, and transport to the stratosphere. ${ }^{(2)}$ UNEP $^{13)}$ emphasized that uncertainties in the global tropospheric ozone budget, particularly in the free troposphere, are mainly associated with uncertainties in the global distribution of ozone itself and its photochemical precursors, especially $\mathrm{CO}$ and $\mathrm{NO}_{x}$. However, the role of heterogeneous processes, including multiphase chemistry, in the troposphere has not been well characterized, plus the catalytic efficiency of $\mathrm{NO}_{x}$ in catalyzing ozone formation in the free troposphere has not yet been confirmed by measurements.

The transport of chemical species between the stratosphere and the troposphere may play an important role in atmospheric chemistry. To assess the enhancement of ozone, carbon monoxide(CO), nitrogen oxides, and aerosols in the troposphere during springtime, the STE due to tropopause folding in the rear of an upper jet streak that shows the strongest mean west winds must be well understood. For example, downward transport from the stratosphere presents a significant source of ozone into the troposphere and constitutes the ultimate removal mechanism for many stratospheric species, including those involved in ozone depletion $^{14)}$. An STE is associated with the weather conditions in the upper trough/cut-off low together with the polar and subtropical jet stream in the mid-latitude ${ }^{15 \sim 17)}$. In particular, Kim et al. ${ }^{18)}$ found that the enhancement of ozone and aerosols(or yellow sand) over Korea during Asian dust events occurred under weather conditions of an upper trough/cut-off low and surface high pressure system. Kondratyev and Varotsos ${ }^{19)}$ also observed a sharp tropospheric ozone increase before the beginning of a cross-tropopause exchange. Therefore, further analysis of the synoptic situation and the history of relevant air parcels is essential. That is, plots and cross-sections of the meteorological parameters, such as the air temperature, geopotential height, wind velocity, potential temperature, and potential vorticity, should all be analyzed to understand the exchange and advection of aerosols, ozone, and other trace gases. 
Accordingly, the current study observed the relative enhancement of ozone, carbon monoxide, nitrogen dioxide, and aerosols at the Earth's surface during recent Asian dust events in springtime in Busan, Korea. The results confirmed that the enhancement of ozone above $100 \mathrm{ppb}$ in springtime was due to carbon monoxide( $\mathrm{CO}$ ) in the presence of $\mathrm{NO}_{\mathrm{x}}$ chemistry. The aerosols and trace gases were found to have been transported from China in the upper troposphere under slow-moving weather conditions associated with an upper trough/ cut-off low and surface high pressure system. Finally, the difference between photochemical reaction and the transport of ozone was simulated using Mesoscale Meteorological Model 5(MM5) and the Urban Ashed Model(UAM).

\section{Relative enhancement of ozone, carbon monoxide, nitrogen dioxide, and aerosols during springtime}

A time series of the $\mathrm{O}_{3}, \mathrm{CO}$, and $\mathrm{NO}_{2}$ surface mixing ratio and aerosol density was derived using ultraviolet photometry, infrared spectroscopy, gas filter correlation spectroscopy, and beta-ray absorption, respectively, at Busan, $\operatorname{Korea}\left(35.23{ }^{\circ} \mathrm{N}\right.$, $\left.129.07{ }^{\circ} \mathrm{E}\right)$ since 1992 . The techniques and types of measurements are introduced by http://www. dasibi.com. The Dasibi models providing the air quality monitoring instrumentation included DASIBI 1008-AH for ozone, DASIBI 3008 for carbon monoxide, DASIBI 2108 for nitrogen dioxide, and DASIBI 7001 for aerosols(PM10). The accuracy of the Dasibi models was also maintained while measuring the air quality(http:// www.dasibi.com).

Fig. 1 shows the topography and air quality monitoring sites(Kwangbok, Sinpyoung, Gamjeon, Dukchun, Bumchun, Daeyeon, Dongsam, Yeonsan, and Jaesong) in Busan, Korea. Since these monitoring sites are located in coastal and metropolitan regions, the air quality can be affected by an emission inventory from a variety of sources and the local air circulation due to topography. Fig. 2 shows the hourly surface concentrations of ozone, carbon monoxide, nitrogen dioxide, and Total Suspended Particulates(TSP, $\mu \mathrm{gm}^{-3}$ ) observed during the period from 30 April to 1 May 1999 at the monitoring sites in Busan, Korea. Ozone enhancements above 100 ppbv were obtained in springtime 1999 in Busan, Korea. In particular, significant improvements in $\mathrm{CO}, \mathrm{NO}_{2}$, and aerosols were also included. The primary ozone maxima at the surface occured between 1200 LST and 1800 LST on 1 May 1999, while the secondary ozone maxima above 80 ppbv were observed between 0000 LST and 0600 LST. The night-time secondary

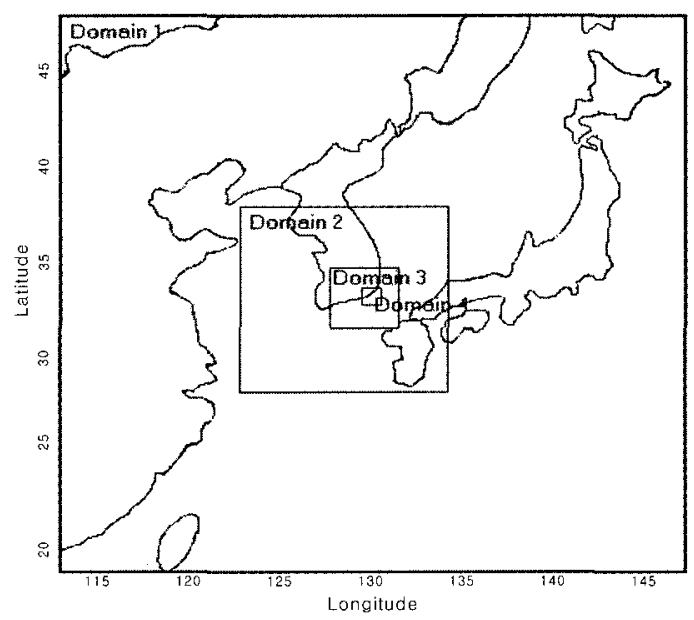

(a)

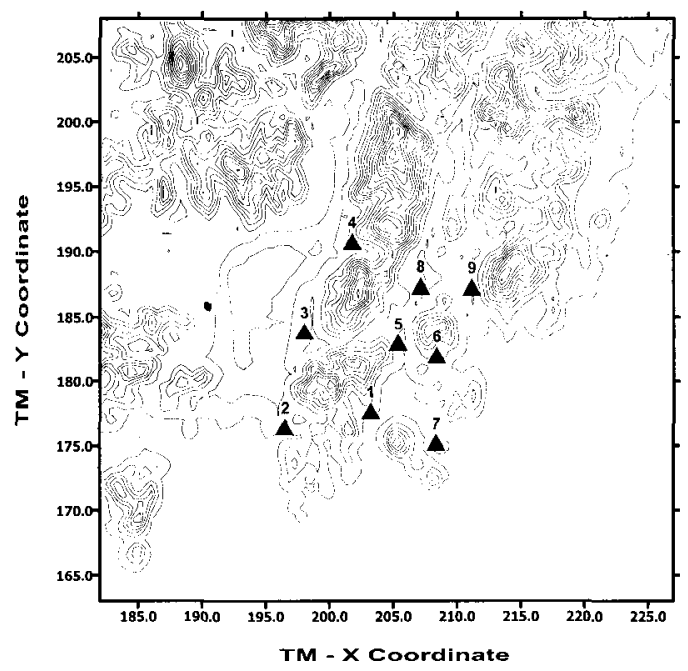

(b)

Fig. 1. (a) Nested grid system used for meteorological model simulation and (b) air quality monitoring sites in Busan, Korea within domain 4. 1: Kwangbok, 2: Sinpyoung, 3: Gamjeon, 4: Dukchun, 5: Bumchun, 6: Daeyeon, 7: Dongsam, 8: Yeonsan, and 9: Jaesong. 


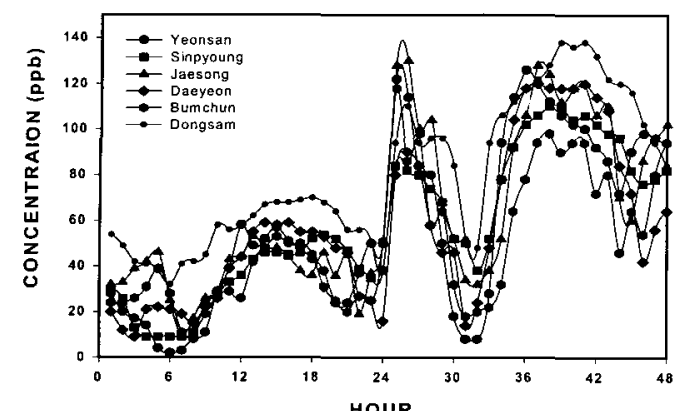

(a)

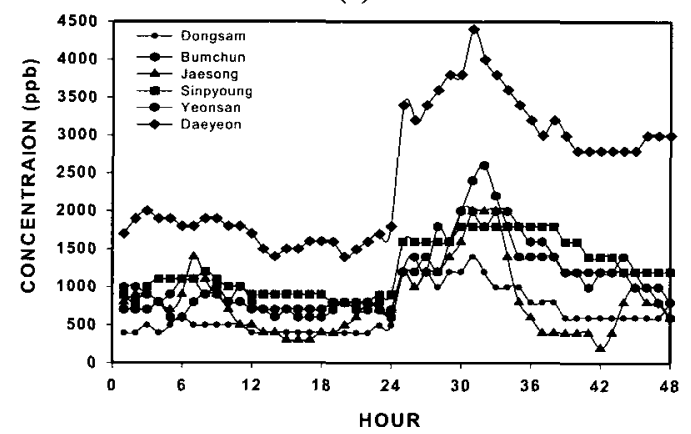

(b)

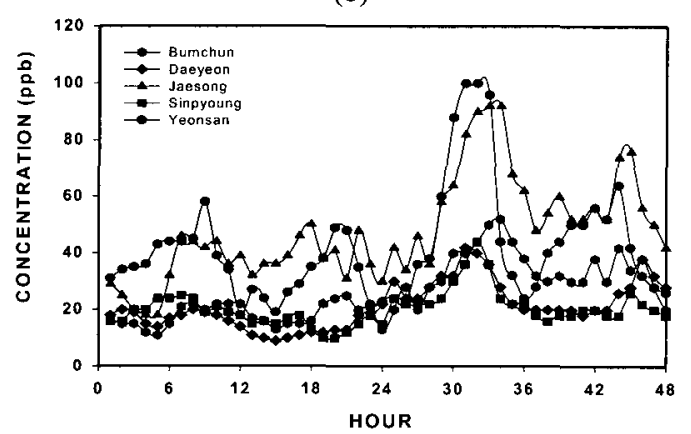

(c)

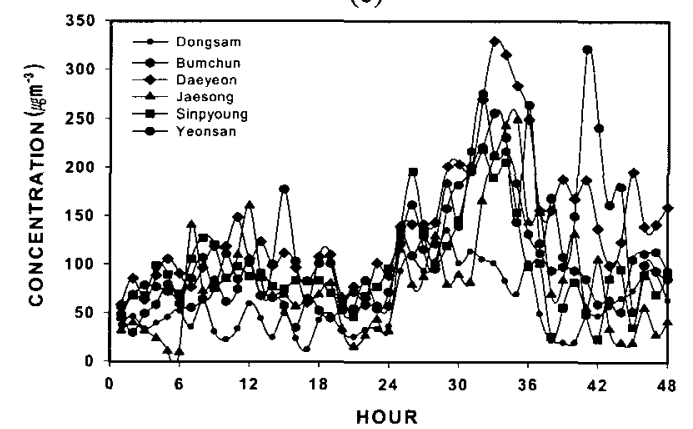

(d)

Fig. 2. Hourly surface concentrations of (a) ozone, (b) carbon monoxide, (c) nitrogen dioxide, and (d) Total Suspended Particulates(TSP, $\mu \mathrm{gm}^{-3}$ ) observed at monitoring sites in Busan. Korea during the period from 30 April to 1 May 1999. ozone maximum at the surface was likely due to invasion from the upper troposphere. The surface mixing ratio of $\mathrm{CO}$ showed a strong positive correlation with that of $\mathrm{NO}_{2}$, and a negative correlation with that of ozone. This indicates that the production of tropospheric ozone was due to the oxidation of $\mathrm{CO}$, including hydrocarbons from natural and anthropogenic origins in the presence of nitrogen oxide radicals, which may have originated downstream of the upper tropospheric air and from the advection of surface emissions (including biomass burning and fossil-feul combustion) in the lower troposphere, as well as hydrogen oxide radicals $\left(\mathrm{HO}_{\mathrm{x}}=\mathrm{OH}+\right.$ peroxy radicals).

In the presence of sufficiently large concentrations of $\mathrm{NO}_{\mathrm{x}}$, the oxidation of $\mathrm{CO}$ will lead to $\mathrm{O}_{3}$ formation with $\mathrm{OH}, \mathrm{HO}_{2}, \mathrm{NO}$, and $\mathrm{NO}_{2}$ acting as catalysts. Carbon monoxide does not react readily with any of the species present in an $\mathrm{NO}_{\mathrm{x}}$-air system. However, carbon monoxide will react with hydroxyl radicals $(\mathrm{OH})$ formed when $O\left({ }^{\mathrm{l}} \mathrm{D}\right)$ atoms collide with $\mathrm{H}_{2} \mathrm{O}$. As such, $\mathrm{OH}$ radicals would appear to be important in the troposphere. Each $\mathrm{O}_{3}$ molecule crossing the tropopause can yield at most two $\mathrm{OH}$ molecules in the troposhpere based on reactions $(1)+(2)$. The absorption of solar ultraviolet radiation with wavelengths shorter than about $320 \mathrm{~nm}$ by ozone leads to the production of electronically excited $O\left({ }^{1} D\right)$ atoms with higherenergy radicals that react with water vapour to produce $\mathrm{OH}$ radicals :

$$
\begin{aligned}
& \mathrm{O}_{3}+\mathrm{hv} \rightarrow \mathrm{O}\left({ }^{1} \mathrm{D}\right)+\mathrm{O}^{2}(\mathrm{O}(\leq 320 \mathrm{~nm}) \\
& \mathrm{O}\left({ }^{\mathrm{l}} \mathrm{D}\right)+\mathrm{H}_{2} \mathrm{O} \rightarrow 2 \mathrm{OH} \\
& \text { Net }: \mathrm{O}_{3}+\mathrm{H}_{2} \mathrm{O} \rightarrow 2 \mathrm{OH}+\mathrm{O}_{2}
\end{aligned}
$$

A large fraction of the $O\left({ }^{1} \mathrm{D}\right)$ atoms are deactivated by collisions with $\mathrm{N}_{2}$ and $\mathrm{O}_{2}$ molecules, yet the remainder generate sufficient $\mathrm{OH}$ to provide a sink for $\mathrm{CO}$ of the required magnitude. In addition, $\mathrm{OH}$ oxidizes methane into formaldehyde $\left(\mathrm{CH}_{2} \mathrm{O}\right)$ and provides a source of $\mathrm{CO}$ based on a reaction with aldehyde radicals(RCHO) and the photolysis of the formaldehyde. Reactions (1) and (2) also lead to the destruction of ozone ${ }^{20)}$.

The chain mechanism for $\mathrm{O}_{3}$ production is shown by the following reaction sequence. Carbon monoxide reacts with the hydroxyl radicals formed in 
reaction (2), then the hydrogen atoms formed in the reaction combine very quickly with $\mathrm{O}_{2}$ to form the hydroperoxyl radical $\mathrm{HO}_{2}$. When $\mathrm{NO}$ is present, the most important atmospheric reaction that $\mathrm{HO}_{2}$ radicals undergo is with NO. The atmospheric oxidation of $\mathrm{CO}$ can be summarized by the $\mathrm{HO}_{\mathrm{x}}$ chemical family $\left(\mathrm{HO}_{\mathrm{x}}=\mathrm{H}+\mathrm{OH}+\mathrm{HO}_{2}\right)$ and $\mathrm{NO}_{\mathrm{x}}\left(\mathrm{NO}_{\mathrm{x}} \equiv \mathrm{NO}+\mathrm{NO}_{2}\right)$ as follows :

$$
\begin{aligned}
& \mathrm{CO}+\mathrm{OH} \rightarrow \mathrm{H}+\mathrm{CO}_{2}(3) \\
& \mathrm{H}+\mathrm{O}_{2}+\mathrm{M} \rightarrow \mathrm{HO}_{2}+\mathrm{M} \\
& \mathrm{HO}+\mathrm{NO} \rightarrow \mathrm{OH}+\mathrm{NO}_{2} \\
& \mathrm{NO}_{2}+\mathrm{hv} \rightarrow \mathrm{NO}+\mathrm{O}(\leq 400 \mathrm{~nm}) \\
& \mathrm{O}+\mathrm{O}_{2}+\mathrm{M} \rightarrow \mathrm{O}_{3}+\mathrm{M} \\
& \mathrm{Net}: \mathrm{CO}+2 \mathrm{O}_{2} \rightarrow \mathrm{CO}_{2}+\mathrm{O}_{3}
\end{aligned}
$$

Where $\mathbf{M}$ is either nitrogen or oxygen, which serve as abundant third-body molecules. This reaction chain is driven by the absorption of solar ultraviolet radiation with wavelengths shorter than about $400 \mathrm{~nm}$ (reaction 6), which is only slightly absorbed by ozone. The net formation of $\mathrm{O}_{3}$ occurs because the conversion of $\mathrm{NO}$ into $\mathrm{NO}_{2}$ is accomplished by $\mathrm{HO}_{2}$ radicals rather than by $\mathrm{O}_{3}$ itself. This set of reactions can occur repeatedly until one of the molecules is removed in a termination reaction ${ }^{14)}$. Plus, the reaction rates are determined by the density of carbon monoxide, $\mathrm{OH}$, and $\mathrm{NO}$ in the atmosphere and the absorption of solar radiation.

In Figs. 2(b) and 1(c), there is a lag time in the reaction between $\mathrm{CO}$ and $\mathrm{NO}_{2}$ due to the chain mechanism for $\mathrm{O}_{3}$ production. As such, this indicates that the production of tropospheric ozone is due to the catalytic oxidation of $\mathrm{CO}$ in the presence of nitrogen oxide radicals. It is also believed that since air temperature variations are usually very well correlated with solar radiation changes, the latter produce variations in the photochemical activity, thereby leading to ozone variability ${ }^{1)}$. In the current study, the air temperature and solar radiation remained constant during the ozone episode from April 30 to May 2, 1999, as shown in Fig. 3, and during the ozone maxima they were about $20{ }^{\circ} \mathrm{C}$ and $320 \mathrm{~W} \mathrm{~m}^{-2}$, respectively. However, the time series of the wind speed was similar to the hourly variation of the surface ozone concentration on 1 May 1999. As such, a strong positive correlation was found between the surface ozone concentration and the wind speed. During the ozone maxima at night and during the day, the highest wind speed was about $6 \mathrm{~m} \mathrm{~s}^{-1}$ and $12 \mathrm{~m} \mathrm{~s}^{-1}$, respectively. This shows that the enhanced ozone late at night and during the day was determined by a strong wind speed resulting from a momentum transfer on the stable layer(called the low-level jet) or a larger gradient between a high- and low-pressure system. At the same time, the production of surface ozone during the day was due to the catalytic oxidation of $\mathrm{CO}$ in the presence of nitrogen oxide radicals occurring in

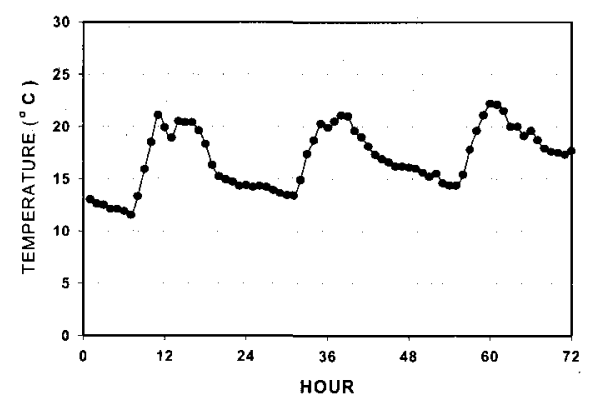

(a)

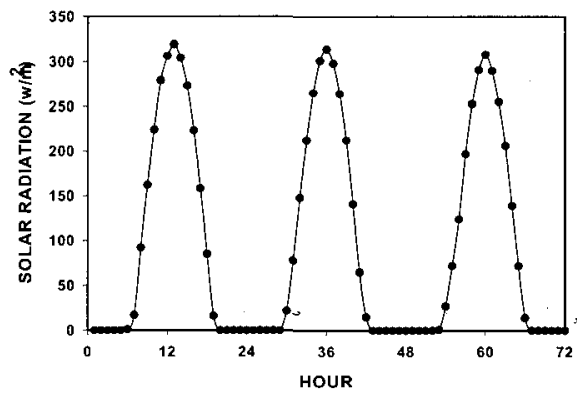

(b)

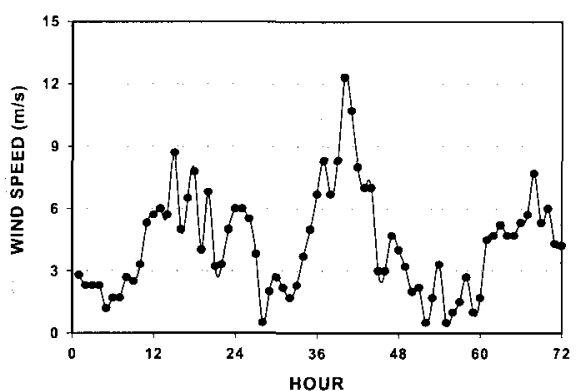

(c)

Fig. 3. Diurnal variations in (a) air temperature, (b) solar radiation, and (c) wind speed during ozone episode period from 30 April to 2 May 1999 in Busan, Korea. 
the early morning. Then, aerosols played an important role as an indicator of the transport of ozone and $\mathrm{CO}$ (see Fig. 2 (d)). It was also found that the diurnal variation of aerosols was similar to that of $\mathrm{CO}$. The origin of the ozone, $\mathrm{CO}$ and aerosols is introduced in sections 3 and 4 .

Hydroxyl radicals $(\mathrm{OH})$ are responsible for the removal of most trace gases from the atmosphere. The actual presence of $\mathrm{OH}$ at the ground-level during daylight was demonstrated by its characteristic ultraviolet absorption feature with the help of a long-path laser beam as the background light source $^{21)}$. Recent differential absorption data obtained with high spectral resolution confirmed the existence of $\mathrm{OH}$ and traced its diurnal variation ${ }^{22-23)}$. It was found that the $\mathrm{OH}$ concentration closely followed the diurnal variation of ozone photodissociation to simultaneously produce $O\left({ }^{1} \mathrm{D}\right)$. This is similar to the diurnal variation of UV-B irradiance. The peak was exhibited from 1000 LST to $1300 \mathrm{LST}^{23)}$. The termination of the chain for $\mathrm{O}_{3}$ production can occur when $\mathrm{OH}$ and $\mathrm{NO}_{2}$ react to form nitric acid, and when $\mathrm{HO}_{2}$ self-reacts to produce hydrogen peroxide $\left(\mathrm{H}_{2} \mathrm{O}_{2}\right)$, yet at this point it is assumed that when the $\mathrm{NO}_{\mathrm{x}}$ concentrations are sufficiently large, the self-reaction of $\mathrm{HO}_{2}$ is not favored during early daytime. The major chainterminating steps in $\mathrm{CO}$ oxidation include nitric acid and hydrogen peroxide formation:

$$
\begin{aligned}
& \mathrm{NO}_{2}+\mathrm{OH}+\mathrm{M} \rightarrow \mathrm{HNO}_{3}+\mathrm{M} \\
& \mathrm{HO}_{2}+\mathrm{HO}_{2} \rightarrow \mathrm{H}_{2} \mathrm{O}_{2}+\mathrm{O}_{2}
\end{aligned}
$$

The principal sink of $\mathrm{NO}_{\mathrm{x}}$ is oxidation into $\mathrm{HNO}_{3}$ in the daytime. Hydrogen peroxide is highly soluble in water and is removed from the atmosphere by deposition, which was measured on a weekly basis. ${ }^{(1)}$ The propagation efficiency of the catastrophic chain(chain length) is determined by the abundance of $\mathrm{NO}_{\mathrm{x}}$ originating from combustion, lightning, and soils. The presence of $\mathrm{NO}_{\mathrm{x}}$ allows the regeneration of $\mathrm{OH}$ consumed in the oxidation of $\mathrm{CO}$ and hydrocarbons, and concurrently provides a major source of $\mathrm{O}_{3}$ in the troposphere to generate additional $\mathrm{OH}$ (see reaction (5)-(7)). In Fig. 2, the $\mathrm{CO}$ and $\mathrm{NO}_{2}$ increased in the early morning, then suddenly changed into $\mathrm{O}_{3}$ together with an increase in $\mathrm{OH}$ radicals due to UV irradiance at $0900 \mathrm{LST}$ on 1 May 1999. Thereafter, the enhancement of
$\mathrm{OH}$ radicals and the self-reaction of $\mathrm{HO}_{2}$ induced a termination of the chain for $\mathrm{CO}$ and $\mathrm{NO}_{2}$ production. As a result, the ozone peak was near 1500 LST due to the time lag of these chemical reactions. The principal sink of $\mathrm{O}_{3}$ in the troposphere is photochemical reactions and dry deposition on the surface. In fact, ozone destruction by photochemical processes involves reactions (1) and (2). Because this removal path depends on the concentration of water vapor, it is most effective in low latitudes at low altitudes, where the radiation is intense and the humidity high ${ }^{14)}$. The reminder is primarily the result of the reaction :

$$
\mathrm{HO}_{2}+\mathrm{O}_{3} \rightarrow \mathrm{OH}+2 \mathrm{O}_{2}
$$

Since photochemical destruction only occurs during daytime, while dry deposition can occurs both during the day and at night, the dry deposition of ozone can effectively compete with chemical removal.

To assess the relative contributions of the transport and chemical reaction of ozone and $\mathrm{CO}$, model simulations are required with meteorological parameters, along with the photochemical process through an emission inventory. Accordingly, the following section introduces the origin of the $\mathrm{O}_{3}$, $\mathrm{CO}$, and aerosols associated with the weather systems using MM5.

\section{Origin of ozone, carbon monoxide, and aerosols during Asian dust events on 1 May 1999}

Based on the secondary ozone maxima and diurnal variation of $\mathrm{CO}$ and aerosols on 1 May 1999, it was found that the ozone, CO, and aerosols were transported from the upper troposphere or boundary layer. At night, nitrate radicals are formed based on the reaction of $\mathrm{NO}_{2}$ with $\mathrm{O}_{3}$, which is strongly temperature dependent ${ }^{24-25}$.

$$
\begin{aligned}
& \mathrm{NO}_{2}+\mathrm{O}_{3} \rightarrow \mathrm{NO}_{3}+\mathrm{O} \\
& \mathrm{NO}_{3}+\mathrm{NO}_{2}+\mathrm{M} \rightarrow \mathrm{N}_{2} \mathrm{O}_{5}+\mathrm{M} \\
& \mathrm{N}_{2} \mathrm{O}_{5}+\mathrm{H}_{2} \mathrm{O} \text { (aerosols) } \rightarrow 2 \mathrm{HNO}_{3}
\end{aligned}
$$

The resulting lifetime of $\mathrm{NO}_{\mathrm{x}}$ is approximately one day ${ }^{11}$. The important role of $\mathrm{HNO}_{3}$ in the troposphere is determined by its functioning as a 
sink for $\mathrm{NO}_{\mathrm{x}}$ and contributors to the precipitation acidity. $\mathrm{HNO}_{3}$ is strong acids that dissociate quantitatively in water to release $\mathrm{H}^{+}$. Thus, in the polluted urban area the main sink for $\mathrm{NO}$ and $\mathrm{O}_{3}$ in the early morning and night in the absence of photolysis may be as follows:

$$
\begin{aligned}
& \mathrm{NO}_{3}+\mathrm{NO} \rightarrow \mathrm{NO}_{2}+\mathrm{NO}_{2} \\
& \mathrm{O}_{3}+\mathrm{NO} \rightarrow \mathrm{O}_{2}+\mathrm{NO}_{2}
\end{aligned}
$$

In Fig. 2(c) shows an enhanced level of $\mathrm{NO}_{2}$ in the early morning and night due to these reactions on 1 May 1999. At this time, the major source of $\mathrm{NO}_{\mathrm{x}}$ was due to automobile combustion of during office hours and the evening rush hour. A number of reactions involving volatile organic compounds (VOCs), such as alkanes, alkenes, and aldehydes, may also become significant in the polluted urban-boundary layer at nighttime and during the day. In general, the concentration of $\mathrm{O}_{3}, \mathrm{CO}$, and $\mathrm{NO}_{2}$ during the night was low, as on 30 April 1999. Therefore, the sudden enhanced levels of ozone and $\mathrm{CO}$ at night may have originated from intrusions of ozone- and CO-rich air from the free troposphere or lower stratosphere.

To confirm the origin of the $\mathrm{O}_{3}, \mathrm{CO}, \mathrm{NO}_{2}$, and aerosols, the weather conditions were investigated using meteorological parameters, such as the geopotential height, ageostrophic and vertical wind velocity, air and potential temperature, and isentrophic potential vorticity using MM5, the total ozone and aerosol index were monitored using a TOMS(Total Ozone Mapping Spectrometer, http:// toms.gsfc.nasa.gov/aerosols/aerosols.html), and the back trajectory was measured using HYSPLIT ${ }^{26)}$. The resolution of MM5 with NCEP/CDAS input data $\left(2.5^{\circ} \times 2.5^{\circ}\right)$ was $30 \mathrm{~km}$ latitude from $20^{\circ}$ $\mathrm{N}$ to $70^{\circ} \mathrm{N}$ and $30 \mathrm{~km}$ longitude from $50^{\circ} \mathrm{E}$ to $170^{\circ} \mathrm{E}$ for 17 standard pressure surfaces between $1000 \mathrm{hPa}$ and $5 \mathrm{hPa}$.

Fig. 4 shows weather maps where the upper level trough/cut-off low was $500 \mathrm{hPa}$ from the surface and the surface high and low pressure system was $1000 \mathrm{hPa}$ from the surface over east Asia on 30 April and 1 May 1999. As such, the sudden enhancement of $\mathrm{O}_{3}, \mathrm{CO}, \mathrm{NO}_{2}$, and aerosols appeared to be associated with the weather conditions between a deepening cut-off low connected with a surface cyclone and a surface anti cy-

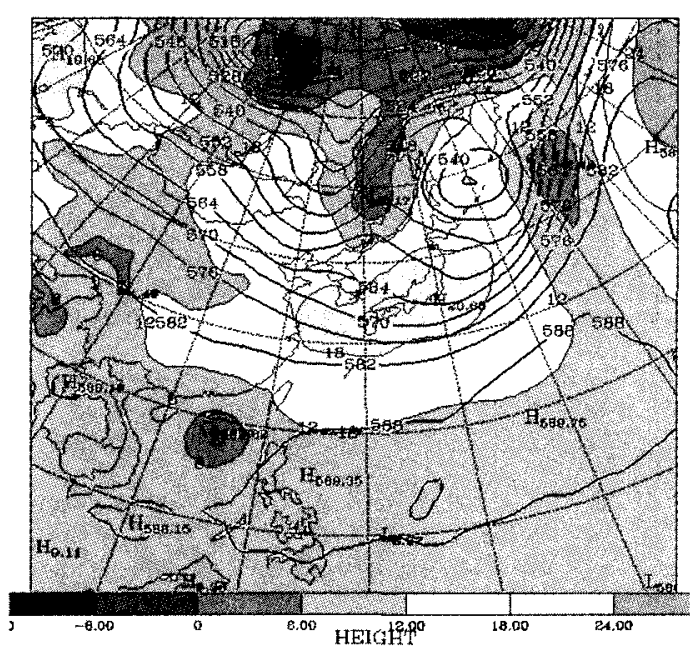

(a)

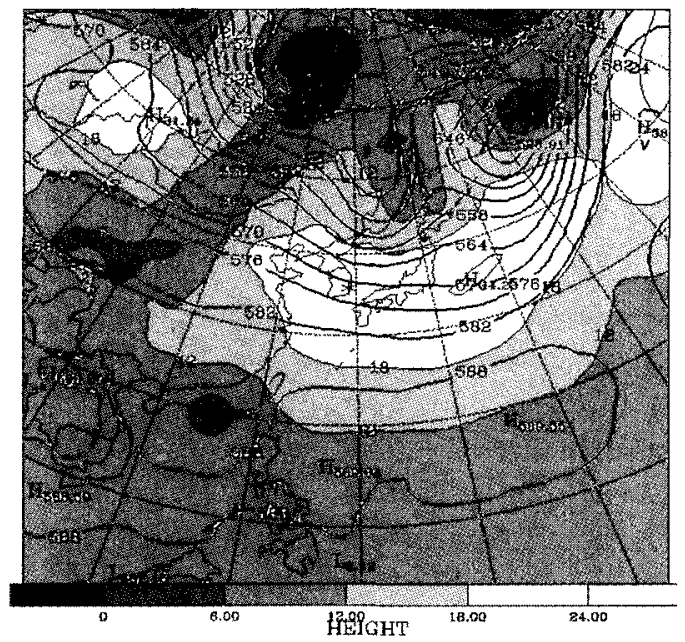

(b)

Fig. 4. Geopotential heights at $500 \mathrm{hPa}$ (thick white lines) and $1000 \mathrm{hPa}$ (shaded lines) at 1500 LST (a) on 30 April 1999 and (b) on 1 May 1999.

clone located under the southern part of the upper trough. In general, there would seem to be a high correlation between this synoptic pattern of geopotential heights at $500 \mathrm{hPa}$ and the distribution of total ozone. As a result, the ozone-rich air in the troposphere and stratosphere within the midand high-latitude was transported with the downward movement of the upper trough/cut off low. Fig. 5 shows the spatial pattern of the TOMS total ozone between 30 April and 1 May 1999. The total ozone increased with the elongated cut-off 


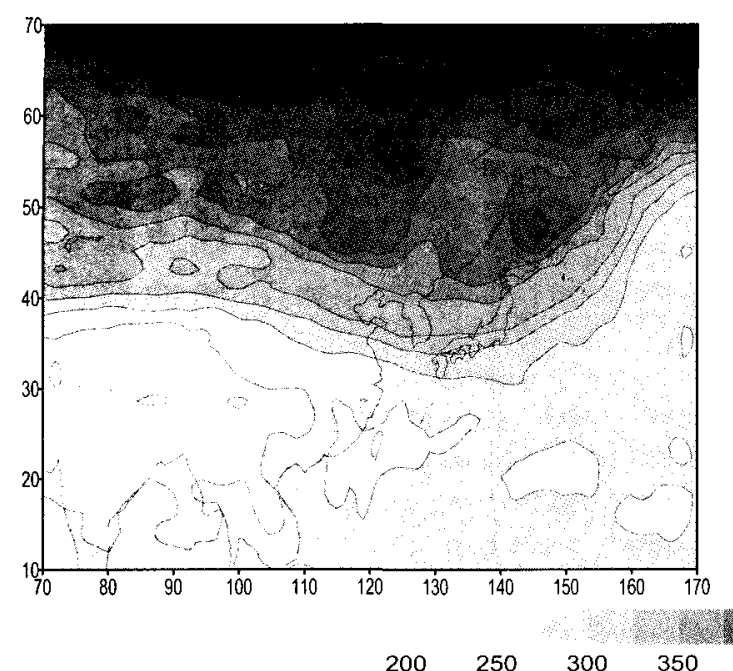

(a)

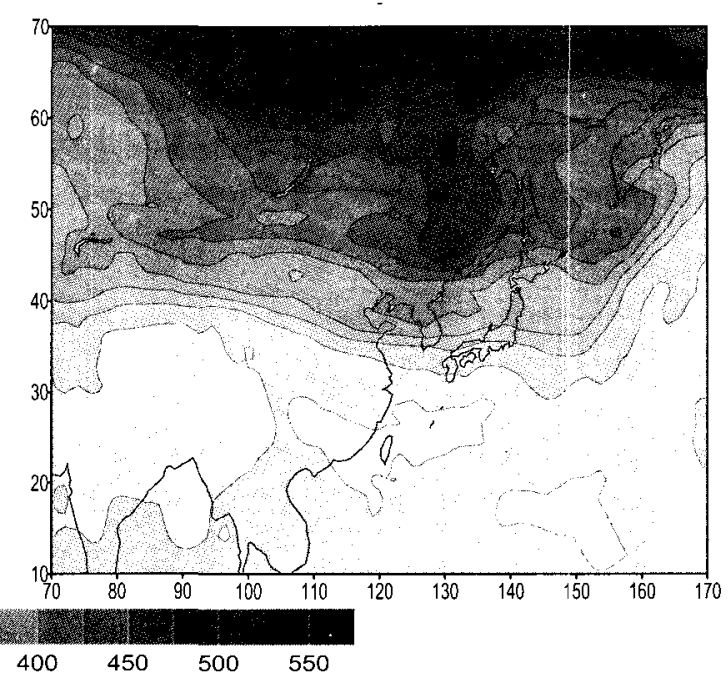

(b)

Fig. 5. TOMS total ozone(Dobson Unit) in east Asia (a) on 30 April 1999 and (b) on 1 May 1999.

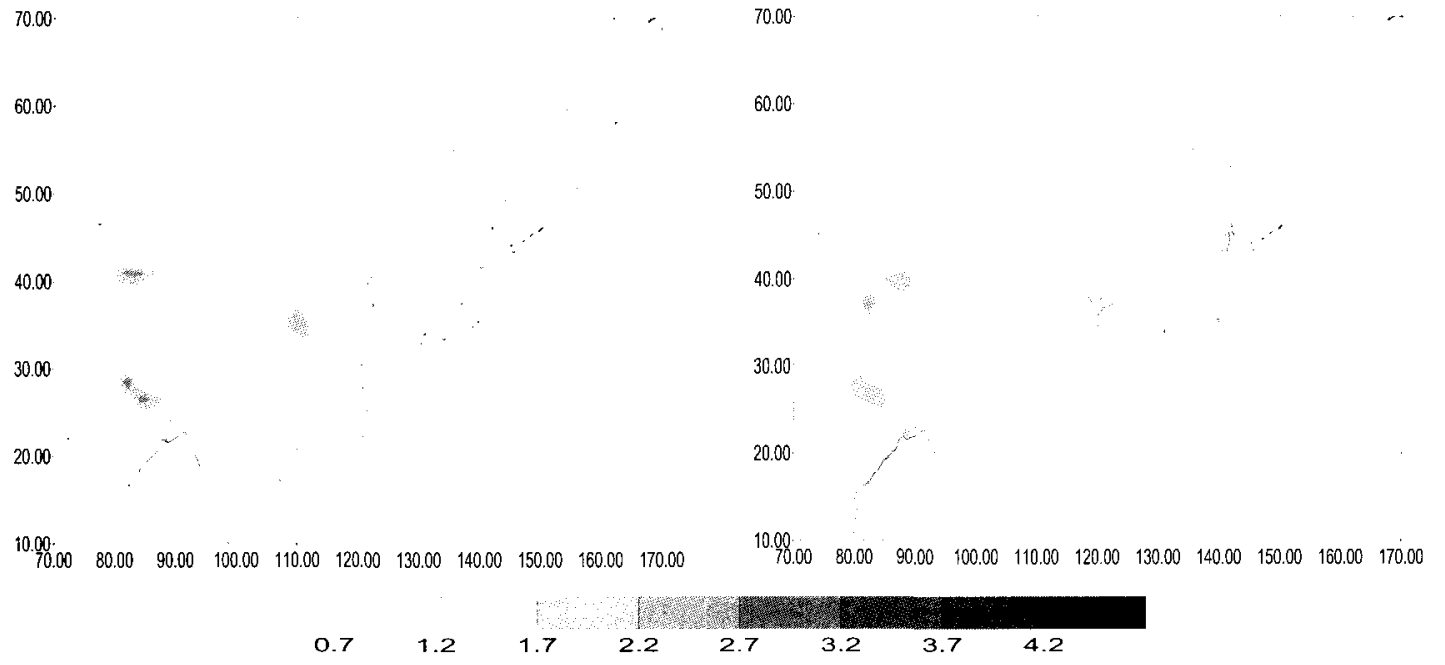

(a)

(b)

Fig. 6. TOMS aerosol index in east Asia (a) on 30 April 1999 and (b) on 1 May 1999.

low over Korea on 1 May 1999. In particular, it was found that the wave pattern of the upper trough/cut-off low together with the total ozone remained stationary despite connecting with a surface cyclone during both days. During these weather conditions of a blocking pattern in springtime, the tropospheric ozone increased with an elongated cut-off low and tropopause folding, plus Asian dust occurred along the desert area below the upper trough associated with the longitudinal and latitudinal distribution of the jet streak that showed a maximum wind speed within the jet stream. ${ }^{27)}$ Fig. 6 shows the TOMS aerosol index on 30 April and 1 May 1999. On 30 April 1999, Asian dust mainly from the Gobi desert in northern China and Mongolia moved across southeastern China to the Pacific Ocean according to route C, as introduced by Sun et al. ${ }^{28)}$ Whereas, on 1 May 1999, Asian dust mainly from the Taklamakan Desert in northwestern China and the Gobi desert moved across the Yellow River, Yellow Sea, and Korea to the Japan Sea, according to route B. As 
such, it was shown that the enhancement of aerosols in Busan, Korea on 1 May 1999 was due to these routes of Asian dust. At the same time, the $\mathrm{CO}$ that accompanied the Asian dust was measured at each monitoring site at 0000 LST and 0700 LST on 1 May 1999, as seen in Figs. 2(b) and 2(d). The enhancement of CO at 0000 LST possibly originated from fossil fuel combustion and biomass burning from China during the Asian dust events. In general, $\mathrm{CO}$ due to biomass is the major source in tropical areas. Using a background tropospheric chemistry model, de Laat et al. ${ }^{29)}$ showed that the spatial distributions of $\mathrm{CO}$ emission from fossil fuel combustion and biomass burning in China comprised about $10 \%$ of the global emission inventory at 32.2 and $59.0 \mathrm{Tg} \mathrm{C} \mathrm{yr}^{-1}$, respectively. Fang et al. ${ }^{30)}$ also suggested that forest biomass carbon storage in China between 1980 and 1998 increased by 4.75 petagrams of carbon. In particular, the concentrations of $\mathrm{CO}, \mathrm{NO}_{2}$, and TSP exhibited one maximum during the morning rush hour at about 7:00. Although the $\mathrm{CO}$ concentration in the case of the Daeyeon site had particularly high values, the variation pattern was still similar to the other monitoring sites.

The exact origin of the $\mathrm{O}_{3}, \mathrm{CO}$, and aerosols present during the Asian dust episodes was analyzed by meteorological parameters using MM5. Figs. 7 and 8 show a vertical cross section of the isentropes $(\mathrm{K})$, ageostrophic wind $\left(\mathrm{m} \mathrm{s}^{-1}\right)$, and vertical wind $\left(10^{3} \times \mathrm{m} \mathrm{s}^{-1}\right)$ velocity, potential vorticity (1PVU $=10^{-6} \mathrm{~m}^{2} \mathrm{~s}^{-1} \mathrm{Kkg}^{-1}$ ), and zonal wind velocity $\left(\mathrm{m} \mathrm{s}^{-1}\right)$ between $\left(17^{\circ} \mathrm{N}, 129{ }^{\circ} \mathrm{E}\right)$ and $(50$ $\left.{ }^{\circ} \mathrm{N}, 129^{\circ} \mathrm{E}\right)$. A typical example of a stratospheretroposphere exchange(STE) was found in the tropopause folding due to the jet stream. Actually, the high ozone levels were correlated with the cut-off low or potential vorticity(see Figs. 4 and 5). The relationship between the total ozone and the potential vorticity has already been used to estimate the stratospheric contribution to the air masses containing elevated ozone in the troposphere $^{31)}$. The isentropic potential vorticity(IPV) is useful as an indicator of the air parcel transport related to the movement of tropopause folding Ertel's isentropic potential vorticity acts a dynamical tracer for distinguishing between stratospheric and tropospheric air as follows :

$$
\mathrm{IPV}=-\mathrm{g} \cdot(f+\zeta) \cdot \partial \theta / \partial p
$$

where $(f+\zeta)$ and $\partial \theta / \partial p$ are the absolute vorticity on the isentropic surface and static stability, respectively. The tropopause values of IPV are generally 1-2 potential vorticity units(1 PVU $=10^{-6} \mathrm{~m}^{2} \mathrm{~s}^{-1} \mathrm{Kkg}^{-1}$ ).

The ozone columnar density(TO) can be expressed as a function of the potential temperature $\theta$ to the level above the surface pressure $P_{\mathrm{s}}$ :

$$
\mathrm{TO}\left(\mathrm{P}_{\mathrm{s}}\right)=-\int_{\theta_{s}}^{\infty}(\chi(\theta) / M g)(\partial p / \partial \theta) d \theta
$$

where $\chi(\theta)$ is a function of the mass mixing ratio between the ozone and the atmospheric density, $\mathrm{M}$ is the ozone molecular mass, $\mathrm{g}$ is the gravitational acceleration, and $\theta_{s}$ is the surface potential temperature.

Equation(17) substituted into Equation(16) is given by :

$$
\mathrm{TO}(\mathrm{Ps})=\int_{o_{s}}^{\infty}(\chi(\theta) / \mathrm{IPV}(\theta))\left(\left(\mathrm{f}+\zeta_{\theta}\right) / \mathrm{M}\right) d \theta(18)
$$

This is the equation that relates the total ozone to the cut-off low or vorticity. Based on the current data, during the development of the cut-off low or vorticity near the tropopause, stretched vortex anomalies increased the total ozone. At same time, the tropopause height became lower, while the upper ridge in the jet stream near the tropopause showed a lower value for the total ozone(see Figs. 5 and 7). As such, it was found that the jet stream played an important role in both the tropopause folding and the boundary for a higher value of total ozone.

In Figs. 7 and 8 the major transport of stratospheric ozone occurred in tropopause folding events associated with the jet stream and cut-off low. In addition, major tropopause folding events have been found to be subject to the influence of the polar front and sometimes to the impact of the subtropical jet stream ${ }^{27}$. Tropopause folding(TF) also occurred also in the rear of the jet streak which showed the maximum wind speed within the jet stream. On 30 April 1999, the STE of ozone can be explained by the TF, the elongated 1-2 IPV anomaly along the tilted potential air temperature, as seen in Fig. 7, due to the jet stream and cut-off low. It was also found that ozone of stratospheric 


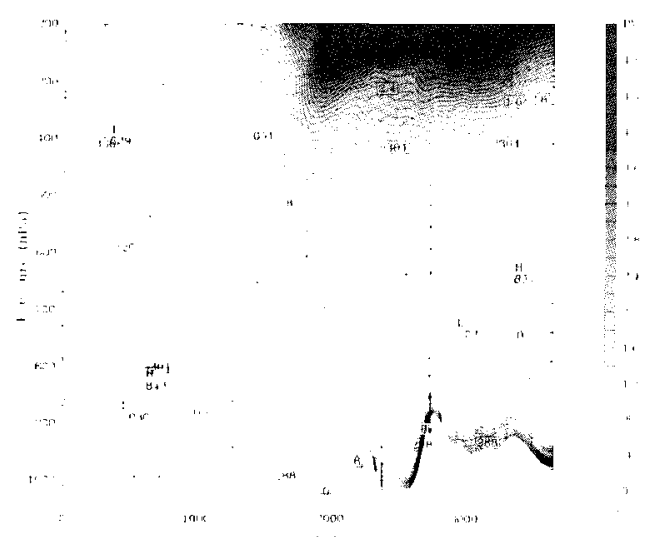

(a)

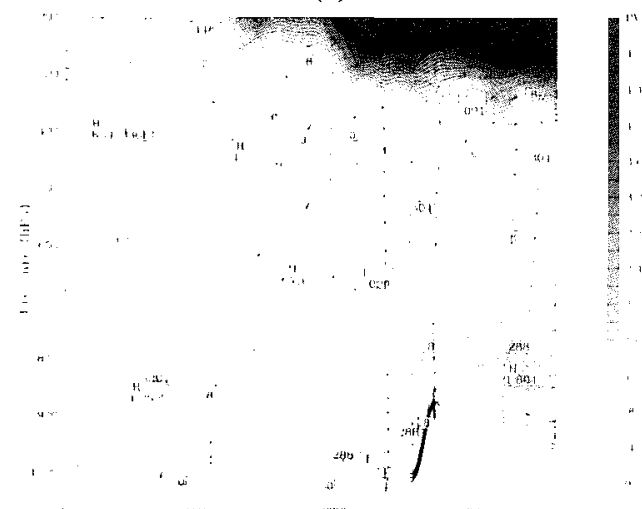

(c)

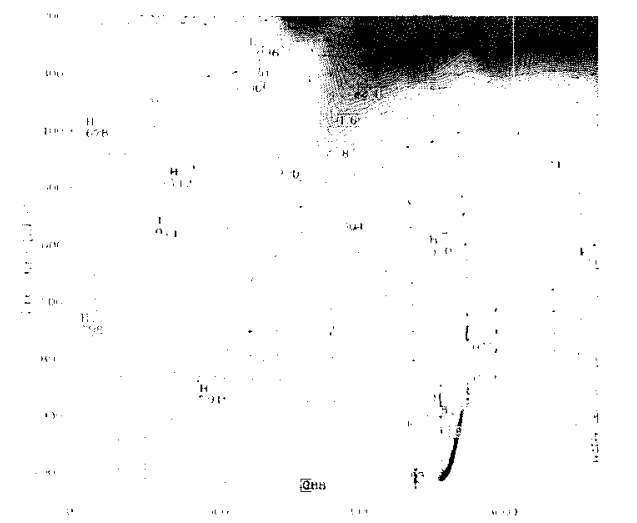

(b)

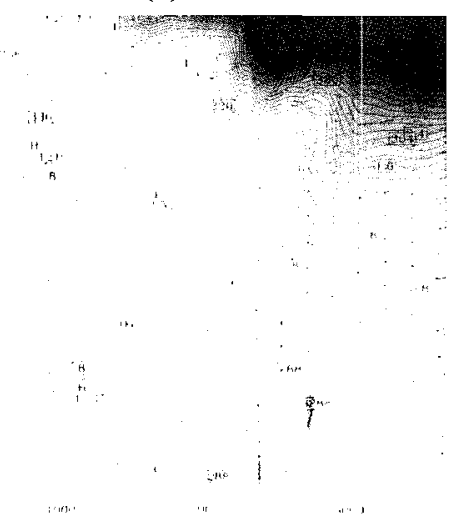

(d)

Fig. 7. Vertical cross section between(17 N, 129 E) and (50 N, 129 E) at (a) 0000 LST on 30 April, (b) 1200 LST on 30 April, (c) 0000 LST on 1 May, and (d) 1200 LST on 1 May 1999 (d). Shown are isentropes $\left(\mathrm{K}\right.$, dotted lines), ageostrophic wind $\left(\mathrm{m} \mathrm{s}^{-1}\right)$ and vertical wind $\left(\times 10^{-3} \mathrm{~m} \mathrm{~s}^{-1}\right)$ velacity(arrows), and potential vorticity (1PVU $=10^{-6} \mathrm{~m}^{2} \mathrm{~s}^{-1} \mathrm{~K} \mathrm{~kg}^{-1}$, solid line) simulated by MM5 using NCEP input data.

origin was transported to $920 \mathrm{hPa}$ above the boundary layer. At the same time, the aerosols and trace gases, such as $\mathrm{CO}$, were transported from China to the south of Korea along the isentropes together with the strong westward wind speed due to the jet stream in the middle troposphere above $700 \mathrm{hPa}$ (see Figs. 6 and 8). These gases and aerosols then accumulated above the boundary layer formed with the development of the mixing layer in the surface anticyclone area located to the south of Korea. At 0000 LST on 1 May 1999, when the jet stream and cut-off low moved north, these gases and aerosols descended to the ground due to a free troposphere-boundary layer exchange near the boundary between the surface anticyclone and cyclone. As a result, sudden enhancements of these gases and aerosols were detected at night at each monitoring site in Busan, Korea. The secondary maxima of ozone above $80 \mathrm{ppbv}$ at night were considered as transport associated due to both an STE in the upper troposphere and a free troposphere-boundary layer exchange. When a time lag occurred for the maxima between the ozone and the $\mathrm{CO}$ or aerosols, this was explained based on the difference in the origin between the STE of ozone due to TF and the advection of $\mathrm{CO}$ and aerosols due to isentropes from China in the troposphere. That is, the difference in concentration between ozone of stratospheric origin and aerosols, ozone, and ozone precursors of tropospheric origin is determined by the anomalies of the TF itself and isentropes below the $\mathrm{TF}^{26}$. The sudden enhancement of ozone during the day was explained both by the catalytic reaction of ozone precursors 


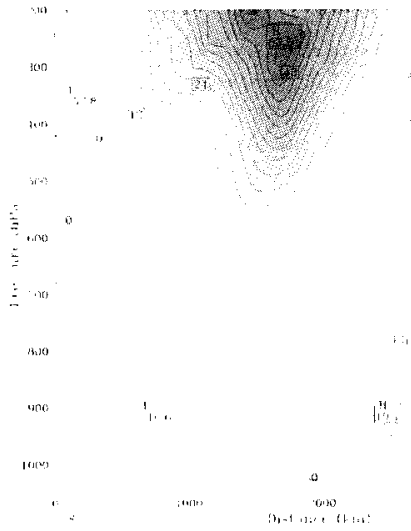

(a)

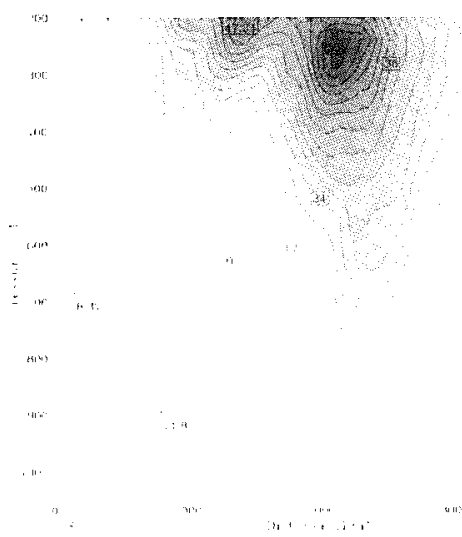

(c)

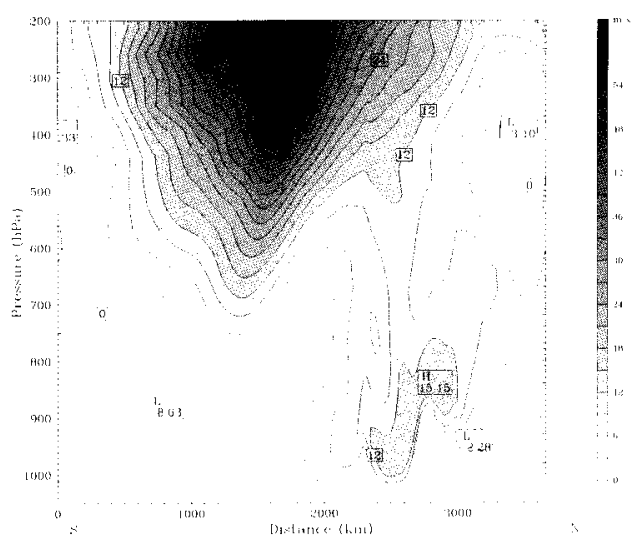

(b)

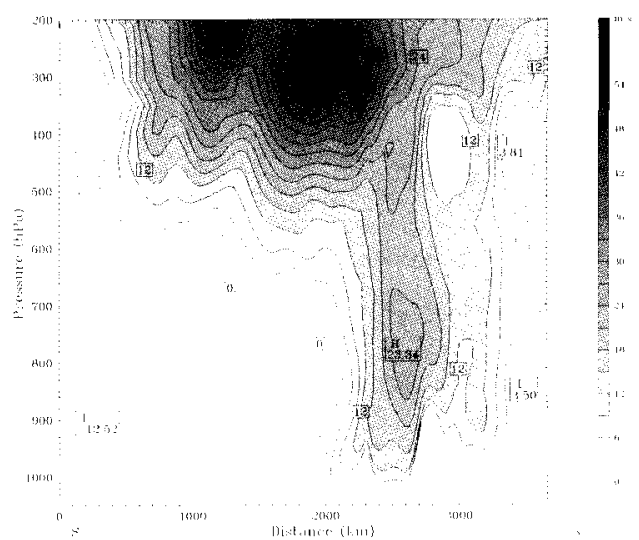

(d)

Fig. 8. Vertical cross section of zonal wind $\operatorname{speed}\left(\mathrm{m} \mathrm{s}^{-1}\right)$ between $(17 \mathrm{~N}, 129 \mathrm{E})$ and $(50 \mathrm{~N}, 129 \mathrm{E})$ at (a) 0000 LST on 30 April, (b) 1200 LST on 30 April, (c) 0000 LST on 1 May, and (d) 1200 LST on 1 May 1999.

and by the transport of ozone from a slow moving anticyclone area located in the south of Korea. In Korea, severe ozone episodes often occur when a slow moving high- and low-pressure system develops in the late springtime. Such slow moving high- and low-pressure weather systems are characterized by a widespread sinking of air through most of the troposphere ${ }^{14)}$. A high- and lowpressure system at the Earth's surface is associated with the development of an upper trough/cut-off low due to the jet stream. As the slow-moving air in the boundary layer passes over major metropolitan areas during Asian dust events, peak concentrations of aerosols, ozone, and ozone precursors can occur due to both transport and catalytic chemical reactions when the solar radiation is high and air temperatures become higher than those of the day before.

The origin of the aerosols and gases was tracked using an isentropic back trajectory model. Fig. 9 shows the isentropic back trajectories using a HYSPLIT model for $1 \mathrm{~km}, 5 \mathrm{~km}$, and $8 \mathrm{~km}$ over Busan, Korea on 1 May 1999. The aerosols measured over Busan, Korea originated from the Taklamakan Desert and Gobi Deserts across the Yellow River on 1 May 1999 in the free troposphere (see Fig. 6). In particular, the $1000 \mathrm{~m}$ profile at 0900 LST and 1200 LST indicated that the source of the air parcels was from an anticyclone located to the south of Korea(see Fig. 4).

Consequently, the ozone enhancement observed during Asian dust events in springtime would appear to be determined not only by the catalytic chemical reaction of ozone precursors, such as $\mathrm{NO}_{\mathrm{x}}$, 


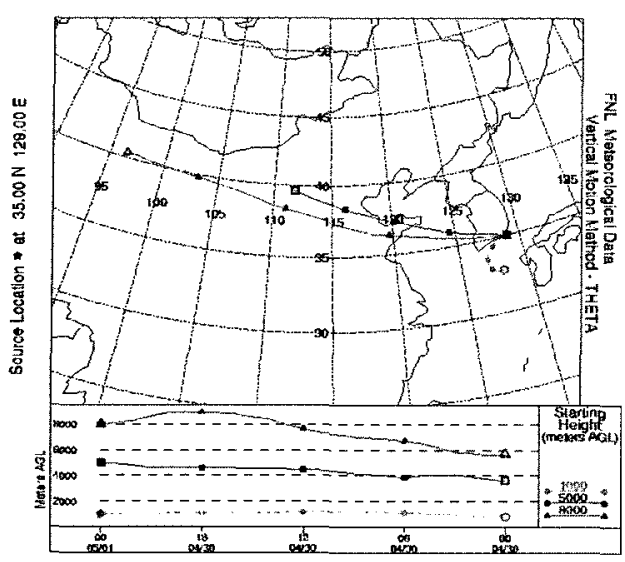

(a)

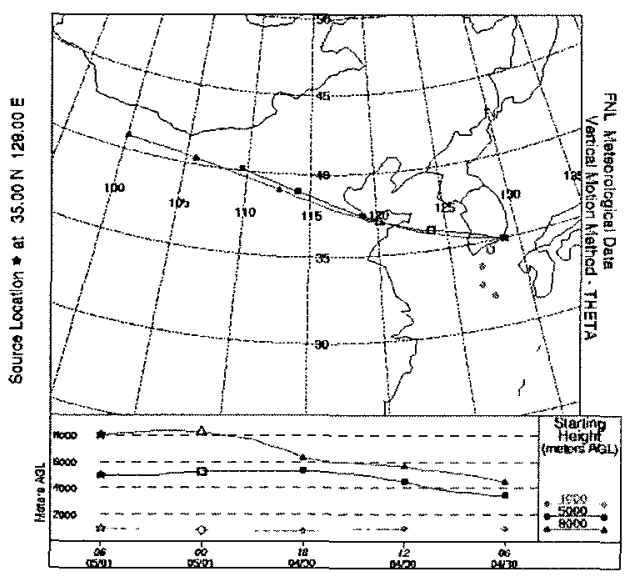

(b)

Fig. 9. Backward trajectories of air mass arriving in Busan at (a) 0900 LST and 1500 LST on 1 May 1999(http://gus.arlhq.noaa.gov/ ready/ hysplit4.html).

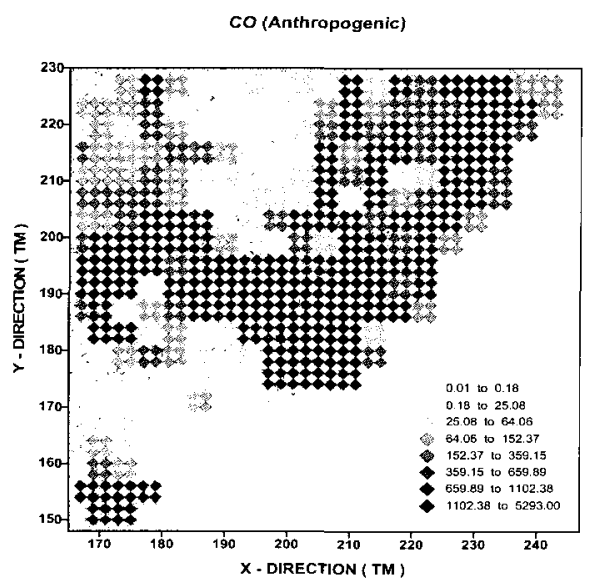

(a)

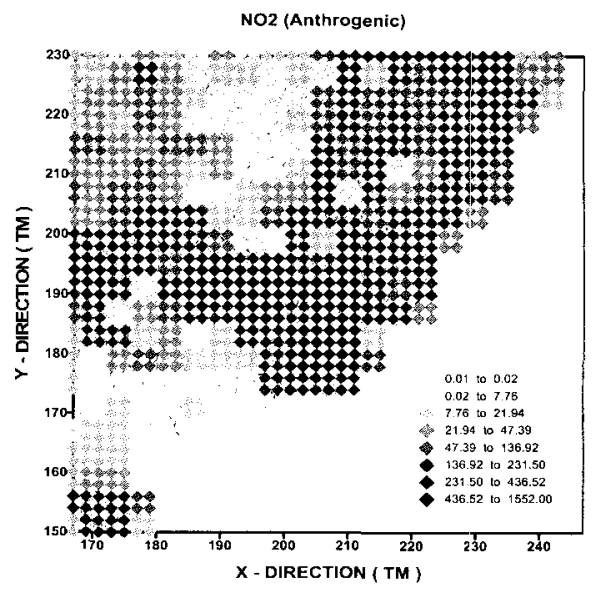

(b)

Fig. 10. Spatial distribution of anthropogenic emission of (a) $\mathrm{CO}$ and (b) $\mathrm{NO}_{2}$ by UAM/ EMISSION in domain 4 during springtime in 1999.
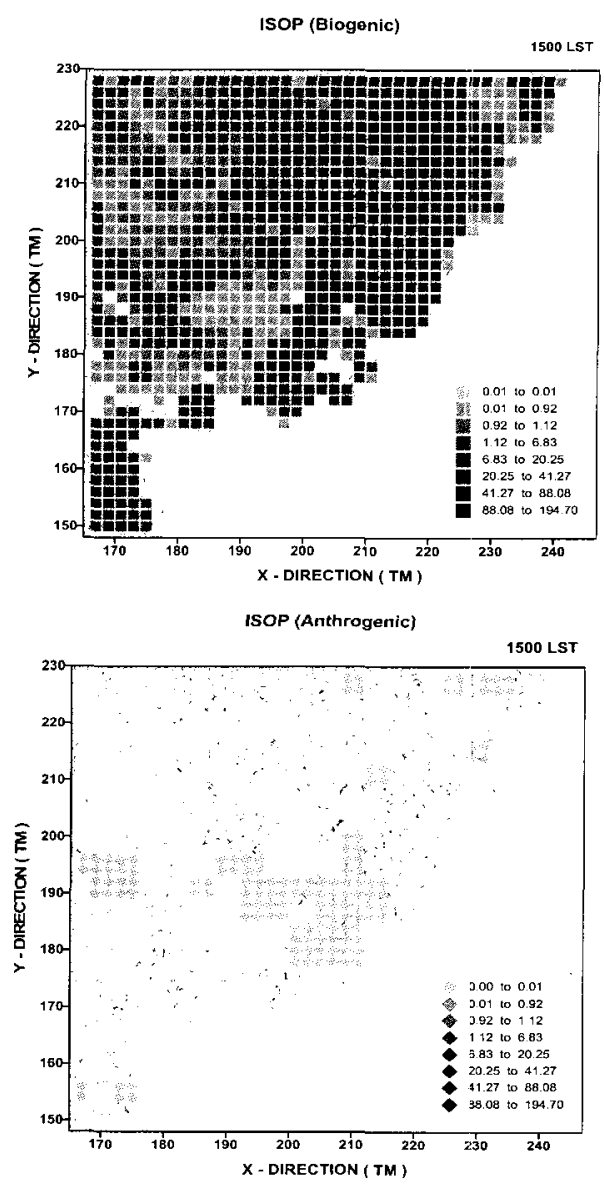

(a) 

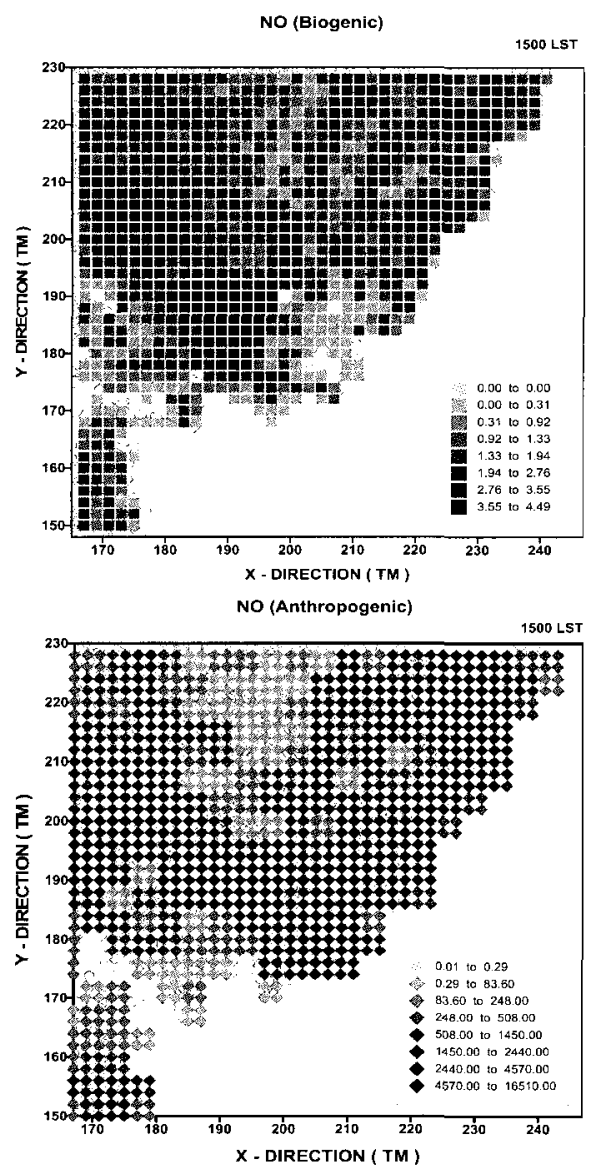

(b)

Fig. 11. Comparisons of biogenic(left) and anthropogenic(right) emissions of (a) isoprene (ISOP) and (b) NO by UAM/ EMISSION in domain 4 during springtime in 1999.

$\mathrm{CO}$, and VOCs(Volatile Organic Compounds), but also by the transport of ozone itself under the slow moving weather conditions of an upper trough/ cut-off low and surface high pressure system. The relative importance of the chemical reactions and transport of these gases in urban areas was analyzed using a photochemical model including the chemical equations introduced by sections 2 and 3 .

\section{Relative importance of chemical reactions and transport of ozone and its precursors using UAM}

The Urban Airshed Model(UAM) and MM5 were used to distinguish the origin and net flux of ozone and ozone precursors from chemical reactions associated with advection within the box relative to transport due to the intrusion of ozonerich air from the free troposphere and long-range advection from the boundary layer during Asian dust events in Busan, Korea on 1 May 1999. The UAM is an Eulerian 3-dimensional photochemical model that uses meteorology, air quality, terrain and emissions data, and the Carbon Bond 4 mechanism(CBM-4). The UAM Modeling System consists of a core model, preprocessors for control, meteorology, and initial/boundary conditions, Emissions Preprocessor System(EPS), Diagnostic Wind Model(DWM), and ROM-UAM Interface Program System(http://www.epa.gov/asmdnerl/ urban.html). In order to consider regularly spaced grid-points of meteorological input parameters, such as winds and air temperature, in UAM, input data from MM5 obtained from the ground-based monitoring sites was used instead of that from DWM. The resolution of MM5 with NCEP/CDAS input data $\left(2.5^{\circ} \times 2.5^{\circ}\right)$ was $2 \mathrm{~km}$ in the $\mathrm{x}$-direction from a $170 \mathrm{TM}$ to $240 \mathrm{TM}$ coordinate and $2 \mathrm{~km}$ in the $\mathrm{y}$-direction from a $150 \mathrm{TM}$ to $230 \mathrm{TM}$ coordinate $(1 \mathrm{TM}=1 \mathrm{~km})$ using an interacting nested grid system, as seen in Fig. 1.

In the case of the emission of pollutants from the Earth' $s$ surface, the input data of biogenic and anthropogenic emissions was considered using the Biogenic Emissions Inventory System(BEIS) that produces hourly biogenic emission rates. Figs. 10 and 11 show the spatial distribution of the biogenic and anthropogenic emissions of $\mathrm{CO}, \mathrm{NOx}$, and isopene(ISOP : a VOC) calculated using the EPS and BEIS of UAM in domain 4 during springtime in 1999. The anthropogenic emissions of $\mathrm{NO}, \mathrm{NO}_{2}, \mathrm{CO}, \mathrm{SO}_{2}$, and THC(Total Hydro Carbon) were estimated from industrial and other combustion sources using a $2 \times 2 \mathrm{~km}$ TM grid. At this point, VOC data for estimating the THC emissions was given as the isoprene, toluene, xylene, paraffinic carbon bond, olefinic carbon bond, formaldehyde, high molecular weight aldehydes, ethene, and ethane emitted from oil tanks, gas stations and other gas sources. Natural emissions of NO, isoprene, and other VOCs were also taken into account based on the emission rates and chemical speciation employed by BEIS-2 for canopy and noncanopy land use types. In particular, 
it was found that biogenic seasonal sources of VOCs, such as isoprene, in Busan, Korea were considerable. Similar spatial distributions of $\mathrm{CO}$ and NOx emissions were also used to depict the catalytic chemical reactions of these gases, as seen in Fig. 2. However, since the estimates of the emission inventory were clearly uncertain, the results of these emissions only represent a lower limit or average value during the springtime from March to May.

Fig. 12 shows the surface fields of the air temperature and wind vectors simulated by MM5 at 0000 LST and 1200 LST on 1 May 1999. The spatial distributions of the air temperature on the Earth's surface are shown parallel to the coast, and the variation in the air temperature simulated by MM5 was similar to that observed at TM coordinate(200, 180), as seen in Fig 3(a). In Fig 12(b) the night and day wind vectors were due to the difference in both the air temperature of the land-sea and high-low pressures of the synoptic scales. As a result, the secondary maxima of ozone above 80 ppbv at night were affected by west-north land breeze, while the first maxima of ozone above $100 \mathrm{ppbv}$ at noon were dominated by a strong east-south or south sea breeze. Therefore, this shows different origins for the surface ozone during the night and day on 1 May 1999 in Busan, Korea. As such, the surface ozone concentration at night was due to vertical mixing and advection from the upper layer above the north region of Busan, as seen in Fig. 7, while that during the midday hours was mainly due to the diurnal photochemical activity and advection of ozone from a high pressure

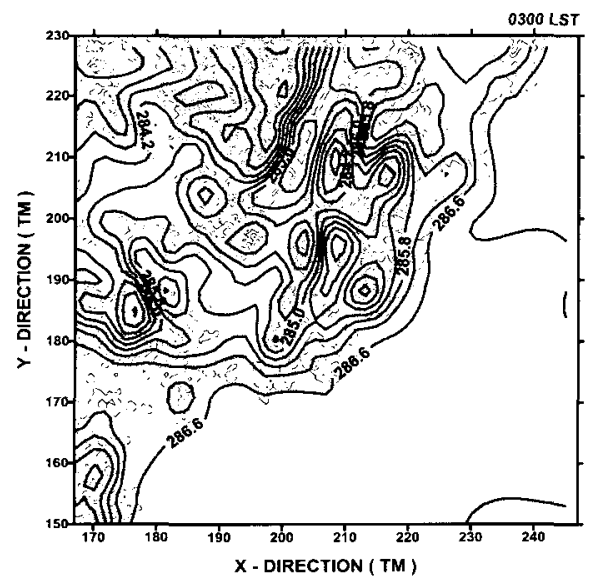

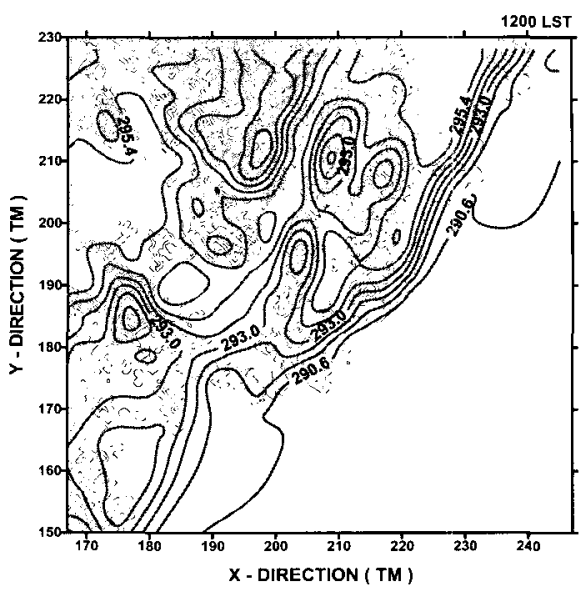

(a)
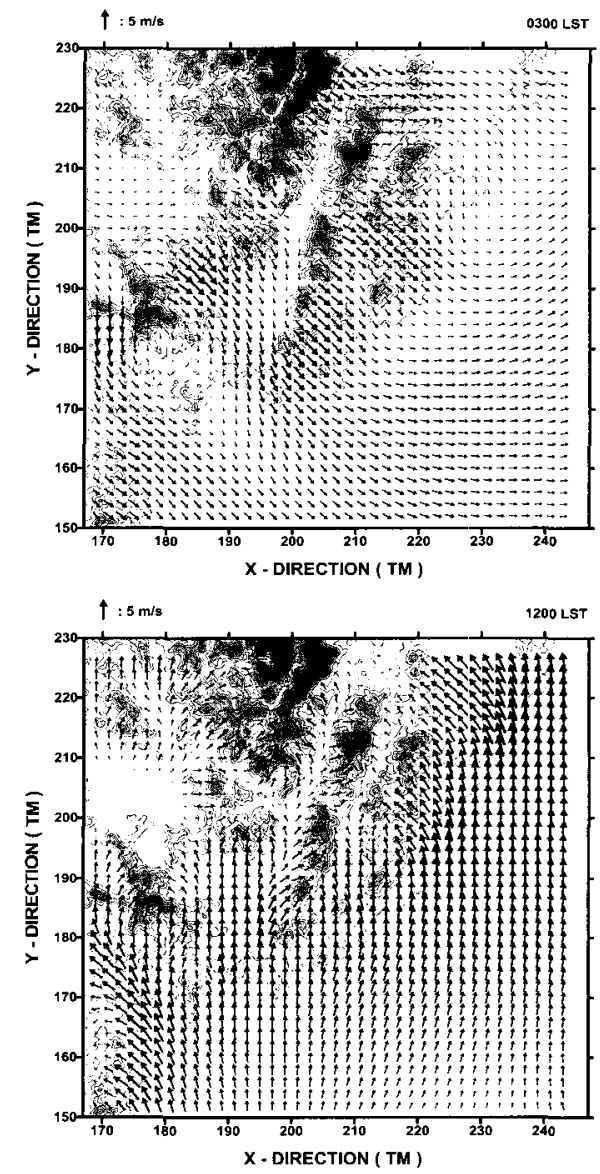

(b)

Fig. 12. Spatial distribution of (a) surface air temperature and (b) wind vector field simulated by MM5 at 0000 LST(left) and 1200 LST(right) on 1 May 1999. 
region with a high content of ozone and its precursors from China. These meteorological parameters were used as the input data for UAM.

Fig. 13 shows the spatial distributions of the surface ozone concentration calculated by UAM at 1200 and $1400 \mathrm{LST}$ on 1 May 1999. UAM was used to simulate three days from April 29 to May 1, 2001. During this period, it was assumed that the affection on the initial boundary condition of each pollutant only continued for one day. The initial concentration was interpolated from the air quality monitoring sites at Busan and other areas in Korea. All the boundary conditions, except for the background concentration resulting from the north side, were assumed to be zero in order to

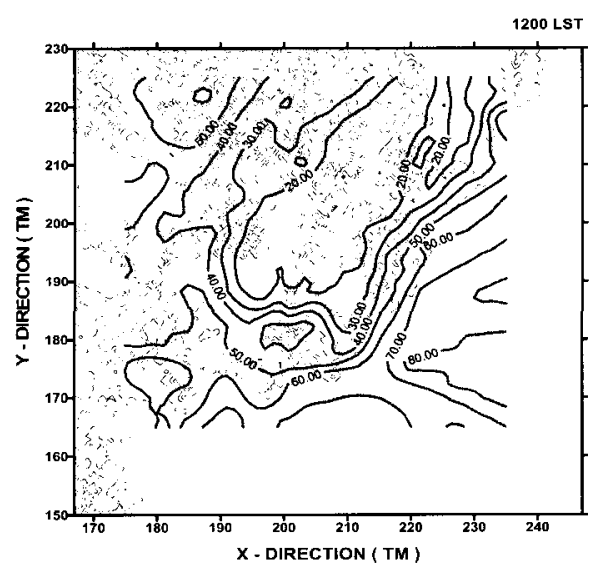

(a)

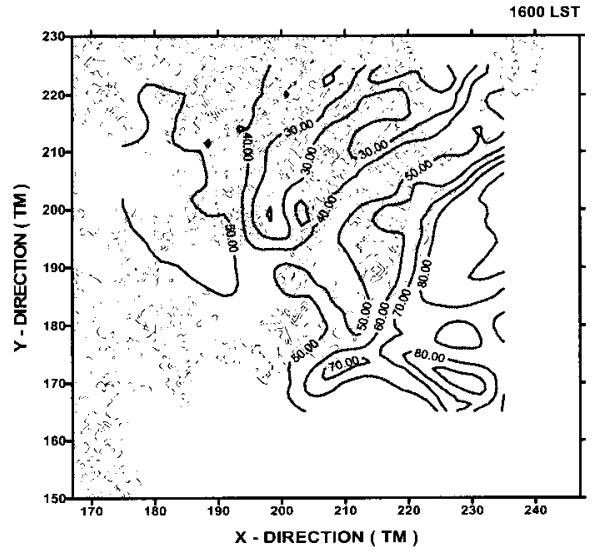

(b)

Fig. 13. Spatial distribution of surface ozone concentration ( $\mathrm{ppb}$ ) calculated by UAM at (a) 1200LST and (b) 1600LST on 1 May 1999. estimate the concentration transported as a result of long-range advection and a free troposphereboundary layer exchange of air pollutants. An enhancement of ozone was found in the coastal region associated with the distribution of the air temperature and wind velocity of the land-sea breeze, as seen in Fig. 12.

The calculated concentrations of ozone and ozone precursors were compared with the groundbased observations. Fig. 14 shows the time series of $\mathrm{O}_{3}, \mathrm{NO}, \mathrm{NO}_{2}$, and $\mathrm{CO}$ at each monitoring site calculated by UAM on April 30 and May 1, 1999. On 30 April 1999, as seen in Figs. 2 and 14, the calculated concentrations of ozone and ozone precursors appeared to underestimate the observed background concentration of ozone and ozone precursors. In the case of ozone and $\mathrm{NO}_{2}$ on 30 April 1999, the difference between the calculated and observed concentrations was about $10 \mathrm{ppbv}$ or more at most monitoring sites, except for the Bumchen, Jaesong, and Dongsam sites. This discrepancy was probably due to the boundary condition of the ozone and ozone precursor concentrations from the free troposphere and background marine region, however, most stations had similar calculated and observed levels of ozone and ozone precursors. It is known that errors in the mixing ratio in a UAM simulation can result from both the boundary condition and emission inventory and the model schemes, such as time-splitting errors that occur when a one-dimensional advection algorithm is applied consecutively to simulate twoor three-dimensional advection ${ }^{32)}$. However, the result using UAM and MM5 was still useful to understand the relationship between the photochemical reaction related to advection in the box

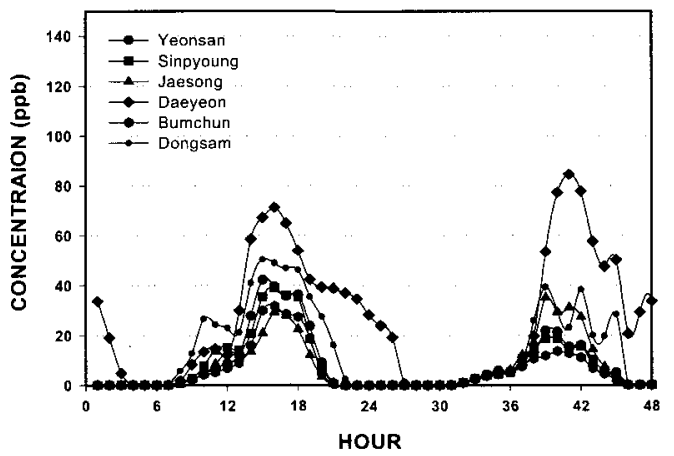

(a) 


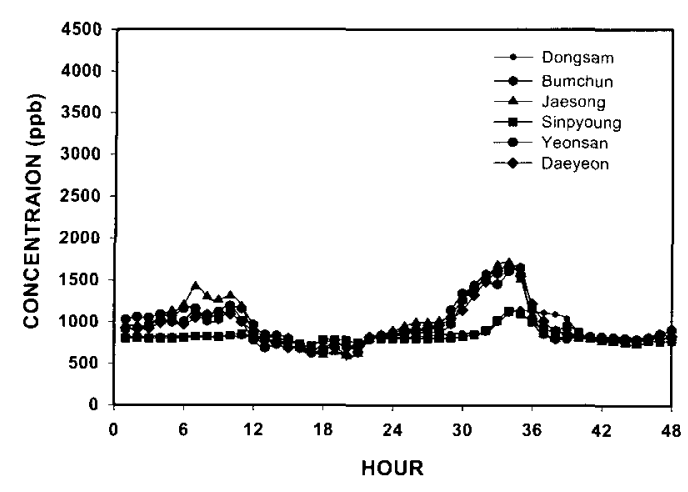

(b)

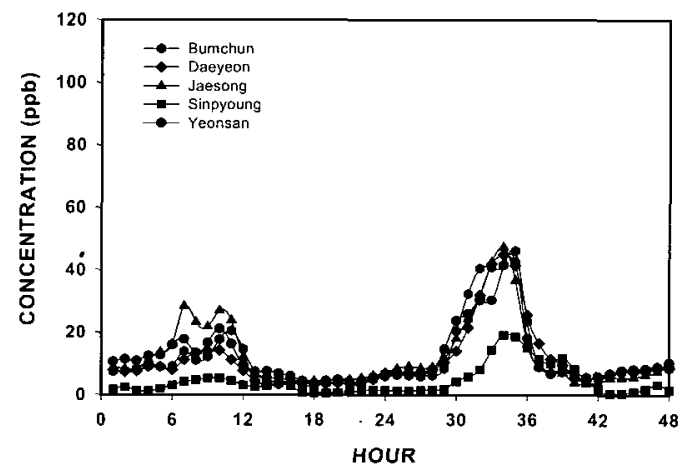

(c)

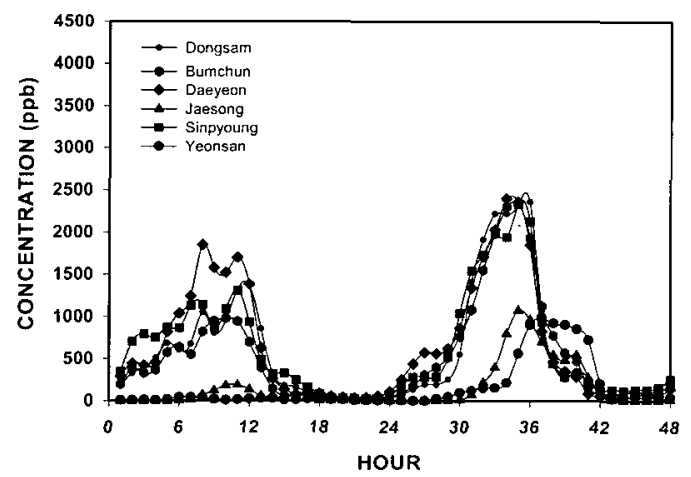

(d)

Fig. 14. Time series of various gases calculated by MM5/UAM at monitoring sites in Busan, Korea from 30 April to 1 May 1999. (a) $\mathrm{O}_{3}$, (b) $\mathrm{CO}$, (c) $\mathrm{NO}_{2}$, and (d) $\mathrm{NO}$.

and the transport originating from long-range advection in the boundary layer and a free troposphere-boundary layer exchange of ozone and ozone precursors. Two invasion events of ozone and ozone precursors were identified from 0000 LST to $0600 \mathrm{LST}$ and $0600 \mathrm{LST}$ to $1200 \mathrm{LST}$ during the Asian dust event on 1 May 1999(see Figs. 2 and 14).

The net flux of the mixing ratio of ozone and ozone precursors due to both long-range advection and vertical convection was also estimated for the Asian dust event on 1 May 1999. In particular, the net flux due to the first invasion of ozone between 0000 LST and 0600 LST on 1 May 1999 agreed with the observed ground-based background concentration of ozone. The origin of ozone was thus due to vertical mixing and advection from the upper layer above the north region of Busan, as seen in Fig. 7. During 0600 LST to 1200 LST, the net flux of the second invasion of ozone was twice as much as the day before. In this case, the origin of ozone due to the photochemical activity and advection of ozone from an anticyclone region that was rich in ozone and its precursors coming from China in the boundary layer of the south sea.

Consequently, it was concluded that Asian dust events in springtime play an important role in both harmful ozone episodes above 100 ppbv through the transport and chemical reaction of a high level of ozone and ozone precursors, and bad visibility through the transport of aerosols under slow moving weather conditions based on correlated development between an upper torough/cut-off low and a surface high- and low-pressure system.

\section{Conclusions}

A time series of the surface mixing ratio of $\mathrm{O}_{3}$, $\mathrm{CO}, \mathrm{NO}_{2}$, and aerosol measurements was derived using ultraviolet photometry, non-dispersive infrared, gas filter correlation, and beta-ray absorption, respectively, from certain monitoring sites in Busan, Korea(35.23 $\left.{ }^{\circ} \mathrm{N}, 129.07{ }^{\circ} \mathrm{E}\right)$ since 1992. An enhancement of ozone above $100 \mathrm{ppb}$ was obtained during the Asian dust event on 1 May 1999. The primary ozone maxima at the surface were observed during the day between 1200 LST and 1800 LST on 1 May 1999, while the secondary ozone maxima above $80 \mathrm{ppb}$ were observed during the night between 0000 LST and 0600 LST. The secondary ozone maxima at the surface were considered to be the result of transport from the free troposphere. The surface concentration of $\mathrm{CO}$ exhibited a strong positive correlation with that 
of $\mathrm{NO}_{2}$, and a negative correlation with that of ozone. Thus, the catalytic increases in $\mathrm{CO}, \mathrm{NO}_{2}$, and aerosols were caused by a deepening cut-off low connecting with a surface cyclone and surface anticyclone located under the south of the upper trough over Korea. The maxima of these gases and aerosols were the result of chemical reactions and a stratosphere-troposphere exchange due to tropopause folding in the rear of the jet streak under these weather conditions. In the presence of sufficiently large concentrations of NOx, the enhancement of ozone was found to be due to the catalytic reaction of $\mathrm{CO}$ originating from fossil fuel and biomass burning emissions from China, the invasion of stratospheric ozone followed by tropopase folding through the elongated downstream of a deep cut-off low associated with the movement of total ozone, and long-range horizontal transport not only from China but also from an anticyclone located in the south of Korea. The difference in concentration between the chemical reaction and the transport of these gases in urban areas was determined using the Urban Ashed Model (UAM), which also included the biogenic and anthropogenic emissions of VOCs and other gases. Accordingly, it was found that the ozone enhancement observed during Asian dust events in springtime would appear to be determined by the catalytic chemical reaction of ozone precursors, such as NOx, CO, and VOCs, along with the transport of ozone under the slow moving weather conditions of an upper trough/cut-off low and surface high pressure system.

\section{Acknowledgements}

This research was supported by the Climate Environment System Research Center sponsored by the SRC program of the Korea Science and Engineering Foundation.

\section{References}

[1] Evans, G., P. Finkelstein, B. Martin, N. Possiel and M. Graves, 1983 : Ozone measurements from a network of remote sites, J. Air Pollut. Control Assoc., 33, $291 \sim 296$.

[2] Girdziene, R., 1991 : Surface ozone measurements in Lithuania, Atmos. Environ.,
25, $1791 \sim 1794$.

[3] Reid, S. T. and G. Vaughan, 1991 : Lamination in ozone profiles in the lower stratosphere, Quart. J. Roy. Meteorol. Soc., 117, $825 \sim 844$.

[4] Mckee, D. J., 1994 : Tropospheric ozone, CRC Press, Boca Raton, FL, p.333.

[5] Prinn, R. G., 1994 : Global atmosphericbiospheric chemistry, Plenum Press, New York, $1 \sim 18$. p.261.

[6] Hales, J., 1996 : Scientific background for AMS policy statement on atmospheric ozone, Bull. Amer. Meteorol. Soc., 77, $1249 \sim 1253$.

[7] Høv, O, 1998 : Transport and chemical transformation of pollutants in the troposphere, Volume 6: Tropospheric ozone research, Springer-Verlag Berlin Heidelberg New York, 341 - 350.

[8] Isaksen, I. S. A., 1998 : Tropospheric Ozone, Regioal and Global Scale Intractions, NATO ASI series, 227, Kluwer, Dordrecht, p.425.

[9] Pazenny, A. and G. Brasseur, 1997 : Tropospheric ozone : An emphasis on IGAC Research. Global Change Newsletter, N30, $2 \sim 10$.

[10] Jaegle, L., D. J. Jacob, W. H. Brune, D. Tar, I. C. Faloona, A. S. Weinheimer, B. A. Ridley, T. L. Campos and G. W. Sachse, 1998b : Sources of HOx and production of ozone in the upper troposphere over the United States, Geophys. Res. Lett., 25, 1705 1708.

[11] Jacob, D. J., 1999 : Introduction to atmospheric chemistry, Princeton University Press, Chichester, West Sussex, pp.143 163.

[12] Hobbs, P. V., 2000 : Introduction to atmospheric chemistry, Cambridge University Press, Cambridge, UK, pp.143 163.

[13] UNEP Scientific Assessment of Ozone Depletion, 1994 : WMO Global Ozone Research and Monitoring Project Report, 37, WMO, Geneva, Switzerland, pp. $1 \sim 20$.

[14] Seinfeld, J. H. and S. N. Pandis, 1998 : Atmospheric chemistry and physics: From air pollution to climate change, John Wiley \& Sons, Inc., New York/Chichester/Weinheim/ Brisbane/Singapore/Tronto, p. 1326.

[15] Austin, J. F. and R. P. Midgley, 1994 : The climatology of the jet stream and stratospheric intrusions of ozone over Japan, Atmo. 
Environ., 28A, 3952.

[16] Davies, T. D. and E. Schuepbach, 1994 : Episode of high ozone concentration at the surface resulting from transport down from the upper troposphere/lower stratosphere : A review and case studies, Atmo. Environ., 28, $53 \sim 68$.

[17] Cooper, O. R., J. L. Moody, J. C. Davenport, S. J. Oltmans, B. J. Johnson, X. Chen, P. B. Shepson and J. T. Merrill, 1998 : Influence of springtime weather systems on vertical ozone distributions over three North American sites, J. Geophys. Res., 103, 22001 -22013 .

[18] Kim, Y. K., H. W. Lee, Y. S. Moon, K. Strong, S. K. Song, Y. K. Lim, and I. B. Oh, 2002 : Mechanism for Asian dust transport during blocking episode days in East Asia and North America in Spring 2001, submitted to Atmos. Environ.

[19] Kondratyev, K. Y. and C. Varotsos, 2000 : Atmospheric ozone variability : Implications for climate change, human health and ecosystems, Springer-Verlag Berlin Heidelberg New York, p.617.

[20] Warneck, P., 2000 : Chemistry of the natural atmosphere, Academic Press, California, U.S.A., p.927.

[21] Perner, D., D. H. Ehhalt, H. W. Pätz, U. Platt, E. P. Röth and A. Volz, 1976 : OH radicals in the lower troposphere, Geophys. Res. Lett., 3, 466 - 468.

[22] Perner, D., U. Platt, M. Trainer, G. Hübler, J. Drumond, W. Jaukermann, J. Rudolph, B. Schubert, A. Volz and D.D. Ehhalt, 1987 : measurements of tropospheric $\mathrm{OH}$ concentrations ; a comparison of field data with model predictions, J. Atmos. Chem., 5, $185 \sim$ 216.

[23] Dorn, H.P., U. Brandenburger, T. Brauers, M. Hausmann and D. H. Ehhalt, 1996 : In situ detection of tropospheric $\mathrm{OH}$ radicals by folded long-path laser absorption : Result from the POPCORN field campain in August 1994, Geophys. Res. Lett., 18, 2, 537-2, 540.
[24] Bandy, A. R., 1995 : The chemistry of the atmosphere-oxidants and oxidation in the Earths atmosphere, Roy. Soc. Chem., Cambridge, UK, p.228.

[25] Barker, J. R., 1995 : Progress and problems in atmospheric chemistry, World Scientific Publishing Co. Pte. Ltd., Singapore/New Iersey/London/hong Kong, 111-171. p.941.

[26] HYSPLIT(HYbrid Single-Particle Lagrangian Integrated Trajectory) Model, 1997 : Web address : http://www.arl.noaa.gov/ready/hys plit4.html, NOAA Air Resources Laboratory, Silver Spring, MD.

[27] Kim, Y. K., H. W. Lee, J. K. Park and Y. S. Moon, 2002 : The Stratosphere- Troposphere Exchange of Ozone and Aerosols over Korea. Atmos. Environ. 36, 449 463.

[28] Sun, J., M. Zhang and T. Liu, 2001 : Spatial and temporal characteristics of dust storms in China and its surrounding regions, 1960-1999 : Relations to source area and climate. J. Geophys. Res. 106, $10325 \sim 10333$.

[29] de Laat, A. T. J., J. Lelieveld, G. J. Roelofs, R. R. Dickerson and J. M. Lobert, 2001 : Source analysis of carbon monoxide pollution during INDOX 1999, J. Geophys. Res.,, 106, $28481 \sim 28495$.

[30] Fang, J., A. Chen, C. Peng, S. Zhao and L. $\mathrm{Ci}, 2001$ : Changes in forest biomass carbon storage in China between 1949 and 1998, Science, 292, 2320 2321.

[31] Fenn, M. A., E. V. Browell, C. F. Butter, W. B. Grant, S. A. Kooi, M.B. Clayton, G. L. Gregory, R. E. Newell, Y. Zhu, J. E. Dibb, H. E. Fuelberg, B. E. Anderson, A. R. Bandy, D. R. Blake, J. D. Bradshaw, B. G. Heikes, G. W. Sachse, S. T. Sandholm, H. B. Singh, R. W. Talbot and D. C. Thornton, 1999 : Ozone and aerosol distributions and air mass characteristics over the South Pacific during the burning season, J. Geophys. Res., 104, $16197 \sim 16212$.

[32] Boybeyi, Z., 2000 : Mesoscale Atmospheric Dispersion, WITpress, Southampton, Boston, pp. $315 \sim 322$. 